Anna Kuśmirek

\title{
„I niosłem was na skrzydłach orlich" (Wj 19, 4) - metafora w tłumaczeniach targumicznych
}

Powszechnie przyjmuje się określenie, że aramejskie przekłady to parafrazy interpretacyjne Biblii Hebrajskiej ${ }^{1}$, które uzupełniają tekst tłumaczony materiałem ilustracyjnym. Według tradycji biblijnej i talmudycznej instytucja targumu ma związek z odczytywaniem Prawa Mojżeszowego „z dodaniem objaśnienia”, aby mógł je zrozumieć zgromadzony lud (Ne 8, 8). Miszna (ok. 200 r. po Chr.) podaje zasady odczytywania i tłumaczenia Pisma w synagodze 2 . Kształtujący się zbiór targumów wiele zawdzięczał zatem synagogalnym tradycjom interpretacji; niektórzy widzą w targumach ślady tego, co można by nazwać starożytnymi zapisami mów synagogalnych. Jednak ustalenie się formy literackiej targumu, jak i jego przekaz zależały również od innych środków.

W targumach możemy znaleźć fragmenty będące w miarę dosłownym przekładem, które jednak uzupełnione jednym słowem bądź krótkim wyrażeniem zawierają aluzję do tradycji interpretacyjnej znajdującej się w literaturze talmudycznej czy midraszowej3. Przekład targumiczny zatem najbardziej zbliża się do tłumaczenia wiernego formalnie, natomiast zewnętrzne dodatki, znajdujące się w nim, a nie mające nic wspólnego z tekstem oryginalnym, zostały zaczerpnięte z tradycji ustnej. Najlepiej byłoby je nazywać kondensacjami lub redukcjami tradycji ustnej do kilku słów-kluczy, których celem było ugruntowanie pozostałej części materiału w umyśle targumisty, kaznodziei oraz słuchaczy ${ }^{4}$.

${ }^{1}$ Zob. Stownik wiedzy biblijnej, red. B. M. Metzger, M. D. Coogan, Warszawa 1997, s. $637 \mathrm{n}$.

2 Tamże, s. 638. Por. R. BAscom, The Targums. Ancient Reader's Helps?, „The Bible Translator" 36 (1985), s. 304-305, s. 304.

${ }^{3}$ Według R. Bascoma pełnej formy należy szukać wśród późnej powygnaniowej i wczesnorabinicznej literatury żydowskiej. Ten trzystopniowy rozwój tekstu (biblijny, targumiczny, rabiniczny) jest możliwy do prześledzenia w synagodze. To tam Biblię czytano po hebrajsku, thumaczono na aramejski opatrując ustnymi uwagami, a ostatecznie przepowiadano jako w pełni rozwinięte kazanie na temat danego tekstu (tamże, s. 301).

${ }^{4}$ Tamże, s. 305. 
Szczególne zainteresowanie budzi także charakter materiału uzupełniającego tekst źródłowy ${ }^{5}$, a także kwestia przekładu na aramejski metafory i alegorii biblijnej ${ }^{6}$.

\section{Metafora biblijna w Wj 19, 4 i jej tłumaczenie w targumach}

Ciekawym zagadnieniem dla badaczy jest stosowanie metafory w tekście Biblii Hebrajskiej i sposób jej przekładu na język aramejski. Stawia się pytania, czy biblijne metafory pozostają niezmienione, czy są one interpretowane przez targumistów i w jaki sposób. Inne rozpatrywane zagadnienie to: Czy tam gdzie oryginalny tekst biblijny - rozumiany w ,podstawowym sensie" - nie odwołuje się do metafory, w targumach zostają stworzone metafory i (lub) alegorie?

\section{Wj 19, 4}

„i niosłem was na skrzydłach orlich”. Powyższe 5 słów - niezależnie od tego, czy uznamy je za metaforę ${ }^{8}$, czy za porównanie - opisują postawę Boga wobec Izraelitów przed teofanią na górze Synaj. Ich dokładne znaczenie pozostaje jednak niejasne ${ }^{9}$. Przekłady aramejskie prezentują różne propozycje tłumaczeń od dosłownych aż do zmian metafory i uzupełnień w tekście:

${ }^{5}$ Por. m.in. W. Chrostowski, Natura i geneza zjawiska targumizmu, PP 4 (1988), s. 83; por. tenże, Ewolucja sensu Tekstu Świętego na przykładzie targumicznej wersji Ez 16, CT 61 (1991), s. 63-80.

${ }^{6}$ Problemem przekładu metafory zajął się np. M. B. DAgut, Metaphor as a Special Translation Problem, Ha-Sifrut 18-19 (1974), s. 120-136; F. BöHL, Die Metaphiosierung in den Targumim zum Pentateuch, FJB 15 (1987), s. 111-149; P. S. Alexander, Tradition and Originality in the Targum of the Song of Songs, [w:] The Aramaic Bible, red. D. R. G. Beattie, M. J. MacNamara, Sheffield 1994, s. 318-339 (JSOTSupp 166); tenże, The Song of Songs as Historical Allegory: Notes on the Development of an Exegetical Tradition, [w:] Targumic and Cognate Studies, red. K. J. CathCARt, M. Maher, Sheffield 1996, s. 14-29 (JSOTSupp 130), a także R. Kasher, Metaphor and Allegory in the Aramaic Translations of the Bible, JAB 1 (1999), s. 53-77.

${ }^{7}$ Por. R. KASHER, Metaphor and Allegory in the Aramaic Translations of the Bible, art. cyt., s. $53 \mathrm{nn}$.

${ }^{8}$ Według klasycznej definicji Arystotelesa w Poetyce, metafora jest to przeniesienie nazwy jednej rzeczy na inną: $\mathrm{z}$ rodzaju na gatunek, z gatunku na rodzaj, z jednego gatunku na inny lub też przeniesienie nazwy z jakiejś rzeczy na inną na podstawie analogii.

${ }^{9}$ Sredniowieczni komentatorzy tak interpretują tę metaforę: „Drogą lądową przeprowadziłem was przez morze, jak orły, które lecąc, przeprawiają się przez morza, a nie doznaliście uszczerbku” (R. Samuel b. Meir - Rashbam); „Ponieważ orła lękają się wszyscy, on zaś niczego się nie boi” (Ibn Ezra - długi komentarz); „ścieżka nie pokonana przez człowieka [...] ma to oddzielić cię od innych narodów i ich działań, abyś był mój” (Seforno). Jak widać, metaforę lub porównanie można interpretować w bardzo różny sposób, niektóre z nich - o ile nie wszystkie - są bardzo prawdopodobne w sensie „znaczenia podstawowego” danego tekstu. Cyt. za R. KASHER, Metaphor and Allegory in the Aramaic Translations of the Bible, art. cyt., s. 56. 
Targum Onkelosa: „Przeniosłem cię jak na orlich skrzydłach”.

T. Neofiti: „I nosiłem cię na chmurach chwały mojej Szekina na skrzydłach zwinnych orłów".

Fragmentaryczny Targum Palestyński: „I przeniosłem cię na obłokach Mojej jeqar šekinta jak na skrzydłach zwinnych orłów”.

Fragmentaryczny Targum Jonatana: „I przeniosłem cię na obłokach mojej jeqar šekinti, przeniosłem jak na skrzydłach orłów”.

Targum Pseudo-Jonatana: „I przeniosłem cię na obłokach jak na orlich skrzydłach z Pelusium, i przeniosłem cię na miejsce Świątyni, byś tam obchodził Paschę, tej samej nocy sprowadziłem cię z powrotem do Pelusium”.

Inne tłumaczenia to Targum Samarytański: „I przeniosłem cię na orlich skrzydłach” oraz Peszitta: „I przeniosłem cię jak na orlich skrzydłach”"

Wymienione przekłady dadzą się sklasyfikować w kilku grupach, w zależności od ich podejścia, jakie reprezentują w tłumaczeniu tej metafory.

\section{Przekłady dosłowne}

Najbardziej dosłowny jest Targum Samarytański. Przekład ten pozostawia nietkniętą pierwotną strukturę, dosłownie oddaje słowo po słowie. Jednak znaczenie tekstu pozostaje niezrozumiałe. Czy zatem zachowanie pierwotnego słownictwa oznacza, że tekst zostaje przetłumaczony literalnie po to, aby obraz miał charakter mityczny, czy też owo literalne tłumaczenie pojmuje tekst jako metaforę-porównanie, lecz technika przekładu - dosłowne oddanie oryginalnego hebrajskiego - trzyma się ściśle pierwotnego języka? Nie wiadomo, jak ten fragment interpretował Targum Samarytański - literalnie czy jako metaforę-porównanie? Metoda translacji literalnej oznacza, że tekst biblijny rzeczywiście zostaje wiernie oddany, łącznie z wyrażeniami obrazowymi. Jednak w takim przypadku zatraca się egzegetyczny zamysł tego wyrażenia. Przekład odzwierciedla więc wybór, jakiego tłumacz dokonał między przywiązaniem do tekstu a chęcią wyjaśnienia go.

\section{Targumy egzegetyczne - jeden mit zamieniony na inny}

Znaczna większość aramejskich przekładów badanego fragmentu wersetu traktuje ten tekst jako porównanie i wobec tego posługuje się aramejskimi wyrażeniami tłumaczonymi słowem ,jak"; tak jest w Targumie Onkelosa, Peszitcie oraz Targumach Palestyńskich: Fragmentarycznym i Pseudo-Jonatana. W każdym z tych przypadków ewidentny wpływ

${ }^{10}$ Por. R. KASHER, Metaphor and Allegory in the Aramaic Translations of the Bible, art. cyt., s. 57. 
na tłumaczenie miało wyraźne porównanie z Pwt 32, 11: „Jak orzeł, co pobudza swe pisklęta (...) tak On rozpostarł swoje skrzydła i zabrał go, przeniósł go na swych skrzydłach". Nawet gdy przyjmuje się, że ten tekst to porównanie, istniejący tu problem egzegetyczny nie jest jeszcze całkiem rozwiązany. Nadal trudno zrozumieć sens tłumaczenia Onkelosa; można tylko przyjąć, że jest to porównanie.

Targumy Palestyńskie częściowo odpowiadają na pytanie dotyczące znaczenia. Obraz Izraela niesionego na orlich skrzydłach przedstawia Izraelitów noszonych na obłokach. Wynikałoby z tego, że w tłumaczeniach dokonano jedynie zamiany jednego obrazu mitycznego („bycie noszonym na orlich skrzydłach”) na inny („bycie noszonym na obłokach”). Zamianę tę widać wyraźnie u Pseudo-Jonatana. Dlatego tekst ten interpretuje się jako mówiący explicite o pewnym mitycznym obrazie, zgodnie z którym Izraelici przenoszeni są na obłokach do świątyni i powracają jeszcze tego samego dnia do poprzedniego miejsca pobytu - Pelusium ${ }^{11}$.

Pomocna w zrozumieniu obrazu mitycznego zawartego w przekładach może być literatura midraszowa. Zarówno wczesne, jak i późne midrasze mówią o obłokach („obłoki chwały”), które towarzyszyły Izraelitom podczas ich wędrówki po pustyni. Ponieważ termin „obłok” często pojawia się w biblijnych relacjach o wędrówkach Izraelitów (m.in. Wj 13, 21; 40, 36-38; Lb 14, 14 itd.), autorzy homilii do tych fragmentów wywnioskowali, że było ogółem 7 obłoków ${ }^{12}$, były jednakże podzielone zależnie od funkcji ${ }^{13}$.

W kontekście przekładów targumicznych warto zwrócić uwagę na fakt, że jest tu mowa o jednym obłoku, który znajdował się pod stopami wędrowców: „oraz jeden pod ich stopami, tak żeby nie wędrowali boso”, czy też w wersji

${ }^{11}$ Zob. Tosefta Targum do Iz 66, 23.

${ }^{12}$ Niektóre autorytety wymieniały 13 obłoków, powołując się na R. Judę, inni z kolei zmniejszali tę liczbę do 4 - jak przypisywano R. Jozjaszowi - czy nawet 2, powołując się na R. Judę Hanasiego. Zob. R. KASHER, Metaphor and Allegory in the Aramaic Translations of the Bible, art. cyt., s. 59.

${ }^{13}$ Niektórzy przypisywali obłokom - lub jednemu z nich - zadanie usuwania przeszkód ze ścieżki Izraelitów idących przez pustynię, np. „Siedem obłoków (...) ten, który posuwał się przed nimi, unosił wszystko co niskie i zniżał wszystko co wysokie. [...] I porażał węże i skorpiony, oczyszczał teren i wyrównywał go przed nimi” (Mechilta Mass. De Vayehi bešallah, Petihta; wersje alternatywne w Mechilta. SbY do Ex 13, 19: „Zaczął cierpieć od słońca, więc [Bóg] rozciągnął nad nim swoje odzienie, jak powiedziano: «Obłok rozpostarł jako osłonę»" [Ps 105, 39]; Midrasz Tanhuma do Pwt 1, 33: „«Jako obłok za dnia»-chodzi o słup obłoku, który ochraniał ich w ciągu dnia, aby nie zaczęli odczuwać pragnienia”). Inni byli przekonani, że obłoki broniły Izraelitów przed spiekotą słońca: „Siedem obłoków chwały (...) a jeden nad ich głowami przed słońcem”; Sifre Zuta, BeHa’alotekha, 33. Oprócz funkcji obłoków źródła mówią też, że otaczały one Izraelitów z czterech stron, jak również z góry i z dołu: „Owe siedem obłoków: cztery na każdej stronie, jeden powyżej i jeden poniżej [według R. Judy: dwa poniżej] oraz jeden podążający przed nimi”, w: Mechilta Mass. De Vayehi bešallah, Petihta. 
midraszu tannaitów do Pwt 1, 31: „«Na pustyni, tam gdzie widziałeś, jak niósł cię Pan Bóg twój» (Pwt 1, 31) - są to obłoki, które ich otaczały, a nawet te znajdujące się pod nimi; «jak mężczyzna nosi swego syna» - jak powiedziano dalej - «nosił go na swych skrzydłach» (Pwt 32, 31)".

Podobnych midraszy jest więcej, np. „R. Eleazar, syn R. Szymona, zapytał R. Szymona, syna R. Jose, syna Lakonia Hama, tymi słowami: jakie jest znaczenie tego wiersza: 'Nie zniszczyło się na tobie odzienie' (Pwt 8, 4)? Czy Izraelici mogli ze sobą mieć na pustyni sprzęt do tkania? Ten mu odpowiedział: Owinęły ich wkoło obłoki chwały, dlatego nie zniszczyli ubrań"14. Podobną homilię można odnaleźć w midraszu do Ps 48, 4, gdzie znajduje się dosłowne wyjaśnienie $\mathrm{Wj}$ 19, 4 i autor nawiązuje do tradycji o obłokach: „Tak jak Święty, niech będzie błogosławiony, zabrał Izraelitów w obłokach chwały i otoczył ich, i niósł ich - jak mówi Pismo: 'I przeniosłem cię na orlich skrzydłach' - tak też obchodzić się będzie z nimi w przyszłości - jak mówi Pismo: 'Kim są ci, którzy unoszą się jak obłoki?' (Iz 60, 8)"15.

$\mathrm{Na}$ podstawie tych tradycji egzegetycznych wierzymy, że Targumy Palestyńskie do $\mathrm{Wj}$ 19, 4, utożsamiając orły z obłokami, dostrzegają w tym wierszu jakieś echo wydarzenia „mitycznego” (pojedynczego), względnie nadal trwającej sytuacji.

\section{Targum Neofiti - możliwość podwójnej koncepcji egzegetycznej}

Przekład Wj 19, 4 przez Neofiti zwraca uwagę na jeszcze inne ważne pytanie dotyczące relacji między dwoma sposobami przekładu: literalnym i egzegetycznym. Jedyny targum, gdzie posłużono się dosłowną translacją (bez względu na możliwe znaczenie egzegetyczne) to Targum Samarytański, natomiast Targumy Palestyńskie i Peszitta stosują system egzegetyczny.

W przekładzie Neofiti: „I przeniosłem cię na obłokach Mojej yeqar šekhinta jak na skrzydłach zwinnych orłów”.

Pierwsza możliwość jest taka, że kopista pominął spójnik. W tym wypadku mielibyśmy do czynienia jednak z innym przykładem palestyńskiej tradycji targumicznej, wedle której słowa stwarzają pewien mityczny obraz i porównanie (obłoki porównane do orłów). Jeśli jednak wersję tę uważać za autentyczną, to możliwa jest interpretacja, iż chodzi o dwojakie tłumaczenie: jedna wersja zawiera porównanie utożsamiające orły z obłokami, druga natomiast jest dosłowna, odnosi się do orłów. Powstaje jednak pytanie: czy

${ }^{14}$ W Deut. Rabba, Ki Tavo obłok spełnia inne zadanie: „Obłok ten szorował odzienie i czyścił je".

${ }^{15}$ Zob. R. KASHER, Metaphor and Allegory in the Aramaic Translations of the Bible, art. cyt., s. 59 n. 
takie połączenie różnych tradycji targumicznych jest dziełem kopistów i przekazicieli tłumaczenia, czy też ten dwojaki przekład jest autentyczną metodą targumiczną interpretującą tekst jako mający podwójne znaczenie?

Na podstawie tłumaczenia Wj 19, 4 w targumach można wskazać, że aramejskie przekłady biblijne mogą zawierać metaforyczne interpretacje tekstu, nawet jeśli nie wymaga tego podstawowe znaczenie tekstu ${ }^{16}$. W ramach uzupełnienia takiej metaforycznej egzegezy można znaleźć liczne przykłady interpretacji alegorycznej. Trzeba jednak zauważyć, że targumy nie pozostawiają alegorii biblijnych bez odpowiedniego objaśnienia. Gdziekolwiek w tekście pojawia się objaśnienie, tam targum jest dosłowny ${ }^{17}$; natomiast tam, gdzie nie ma wyraźnego objaśnienia alegorii ${ }^{18}$ biblijnej, targum dostarcza wyjaśnienia alegorycznego ${ }^{19}$, często korzystając z innego fragmentu Pisma.

Lektura tekstów targumicznych w porównaniu z ich rabinicznymi opracowaniami wskazuje, że często wprowadza się drugi tekst biblijny w celu dostarczenia punktu wyjścia egzegezy rabinicznej (zazwyczaj midraszowej). Teksty wiążące nie pochodzą zwykle z Pięcioksięgu, lecz często z Księgi Psalmów lub poetyckich fragmentów Proroków. Targumistom zatem przyświecał cel formalnego zachowania zarówno tekstu biblijnego, jak i tradycji ustnej. Uzupełnienia, jakimi opatrują tłumaczony tekst, są zgodne z zewnętrzną tradycją interpretacyjną, do której się odnoszą.

Warszawa

ANNA KUŚMIREK

\section{Summary}

„I carried you away on eagle's wings" (Ex 19: 4) - the metaphor in targumic translation

The phenomenon of biblical metaphor has been discussed in the context of Aramaic translation. This article will attempt to illustrate targumic approach to the biblical metaphor or simile from Ex 19:4 „I carried you away on eagle's wings”. These translations may be classified into several groups: literal translation - word for word (Samaritan Targum), exegetical targums - one myth exchanged for another (Palestinian Targums - identification the eagles with the cloudes) and a twofold exegetical conception (T. Neofiti I).

${ }^{16}$ Kasher uważa, że jest to cecha wszystkich targumów, dotycząca wszystkich fragmentów biblijnych, przypuszczalnie wskazująca na niepewność co do faktycznego znaczenia tekstu biblijnego i wyrażająca światopogląd tłumaczy - tamże, s. 64n.

${ }^{17}$ Zob. Targum Jonatana do Ez 15, 2-5; 17, 3-10; 21, 2-4.

${ }^{18}$ Alegoria to pojedynczy motyw lub rozwinięty zespół motywów w utworze literackim, który poza znaczeniem dosłownym ma jeszcze inne, ukryte i domyślne - zob. Słownik terminów literackich, red. J. SŁAwIŃski, wyd. 3 poszerz. i popr., Wrocław 2000, s. 23.

${ }^{19}$ Zob. Targum Jonatana do Ez 19; 23; 24,3 itd. 